\title{
Potencjał odżywczy i bioaktywny odmian owsa zwyczajnego
}

\author{
Nutritive and bioactive potential of oat cultivars
}

\section{Damian Gołębiewski ${ }^{\bowtie}$, Danuta Boros, Kinga Gołębiewska, Anna Fraś}

\author{
Instytut Hodowli i Aklimatyzacji Roślin — Państwowy Instytut Badawczy, Radzików \\ $\triangle$ e-mail: d.golebiewski@ihar.edu.pl
}

\begin{abstract}
Badania miały na celu charakterystykę składu chemicznego ziarna oplewionego i obłuszczonego, a także ocenę wpływu warunków uprawy na cechy fizykochemiczne odmian owsa zwyczajnego. Materiałem badawczym było ziarno oplewione i obłuszczone 22 odmian owsa, a także 3 odmian form nagich, z kolekcji HR Strzelce. W materiale oznaczono udział plewki, składniki mineralne, białko, lipidy ogółem, oligocukry, kaloryczność, skrobię strawną, nieskrobiowe polisacharydy z podziałem na frakcję rozpuszczalną i nierozpuszczalną, $\beta$-glukan oraz ligninę Klasona.
\end{abstract}

\begin{abstract}
Słowa kluczowe: owies, składniki odżywcze, składniki bioaktywne
The research was aimed at characterizing the chemical composition of husked and decorticated grains, as well as assessing the impact of growing conditions on the physicochemical characteristics of oat varieties. The research material was husked and hulled grain of 22 oat varieties, as well as 3 varieties of naked forms, from the HR Strzelce collection. In the material, the share of hulls, minerals, protein, total lipids, oligosugars, calorific value, digestible starch, non-starch polysaccharides divided into soluble and insoluble fraction, $\beta$-glucan and Klason lignin were determined.
\end{abstract}

Key words: oat, nutrients, bioactives

\section{Wstęp}

Rozwój cywilizacji w ostatnich latach przyniósł ze sobą rozpowszechnienie nieprawidłowego stylu życia. Mała aktywność fizyczna, używki, nadmiar stresu, ale przede wszystkim złe odżywianie to główne jego elementy. Wszystkie wyżej wymienione czynniki są przyczyną rosnącej liczby chorób cywilizacyjnych. Jednym ze sposobów poprawy stanu zdrowia społeczeństwa jest konieczność zmiany sposobu odżywiania. W codziennej diecie powinny się znaleźć produkty, które korzystnie wpływają na nasze zdrowie. Przykładem może być owies, który jest unikalnym zbożem o odmiennym od innych zbóż składzie chemicznym. Zawiera składniki odżywcze i bioaktywne, które decydują zarówno o jego przydatności w żywieniu zwierząt oraz człowieka. Ma mniejszą ilość skrobi, a wysoką nieskrobiowych polisacharydów rozpuszczalnych $\mathrm{w}$ wodzie, $w$ szczególności $\beta$-glukanu, stanowiących podstawowe składniki błonnika pokarmowego ziarna owsa. Wykazano jego zdolność do obniżania poziomu cholesterolu i glukozy we krwi poprzez wpływ na zwiększenie lepkości treści jelitowej (Tiwari, 2011). Taki skład ziarna owsa nadaje produktom $\mathrm{z}$ niego wytworzonym wyjątkową wartość żywieniową, a także prozdrowotną.

Niniejsze badania miały na celu charakterystykę składu chemicznego ziarna oplewionego i obłuszczonego, a także ocenę wpływu warunków uprawy na cechy fizykochemiczne odmian owsa zwyczajnego. Uzyskane wyniki umożliwiły wyodrębnienie genotypów owsa najbardziej przydatnych do produkcji żywności funkcjonalnej.

\section{Metodyka}

Materiałem badawczym było ziarno oplewione i obłuszczone 22 odmian owsa, a także 3 odmian form nagich, $\mathrm{z}$ kolekcji HR Strzelce $\mathrm{z}$ doświadczeń polowych w Polanowicach i Choryni w 2016 roku. W materiale oznaczono następujące parametry fizykochemiczne: plewka, składniki mineralne (AACC 08-01), białko (AACC 46-30, 2003), lipidy ogółem (Marchello i in., 1971), oligocukry (Knudsen i Li, 1991), kaloryczność, skrobia strawna (AACC 76-13, 2003), nieskrobiowe polisacharydy (NSP) z podziałem na frakcję rozpuszczalną (S-NSP) i nierozpuszczalną (INSP)( Englyst i Cummings, 1984), $\beta$-glukan (AACC 32-23, 2003) oraz lignina Klasona (Theander i in., 1995). Wyniki przedstawiono w przeliczeniu na \% suchej masy (AACC 44-15A, 2003).

\section{Wyniki}

Zawartość lipidów była cechą najbardziej różnicującą ziarno oplewione badanych odmian owsa pod względem składników odżywczych w przypadku materiału z Choryni ( $\mathrm{CV}=12,4 \%)$, zaś 
w przypadku Polanowic, białko $(\mathrm{CV}=14,5 \%)$. $\mathrm{W}$ odniesieniu do pozostałych składników odżywczych zmienność ich zawartości mieściła się w zakresie $5,3-10,3 \%$ i $4,3-12,1 \%$ odpowiednio w przypadku materiału z Choryni i Polanowic. Ziarno oplewione zawierało średnio $11,4 \%$ białka, lipidów 5,4\%, skrobi 41,7\%. Lokalizacja uprawy istotnie wpływała na zawartość białka, skrobi i sumę składników odżywczych w ziarnie oplewionym. Pozbawienie ziarna plewki kwiatowej wpłynęło na względny wzrost zawartości większości składników odżywczych ziarna owsa. Ziarno obłuszczone przewyższało ziarno oplewione pod względem zawartości białka, lipidów, a także skrobi, odpowiednio o $29 \%, 28 \%, 37 \%$. W konsekwencji ziarno obłuszczone genotypów z Choryni i Polanowic przewyższało o $32 \%$ sumę składników odżywczych (SSO) ziarna oplewionego.

Zawartość składników bioaktywnych charakteryzowała się zróżnicowaniem w zakresie 9,0-14,1\% (Choryń) oraz 7,3-15,7\% (Polanowice). Zawartość frakcji nierozpuszczalnej nieskrobiowych polisacharydów (I-NSP) wyniosła średnio $17,8 \%$, a frakcji rozpuszczalnej NSP 3,2\%. Średnia zawartość ligniny $\mathrm{w}$ ziarnie owsa oplewionego wynosiła $10,8 \%$, a całkowitego włókna pokarmowego (TDF) 31,8\%. Wykazano istotne różnice między lokalizacjami w stosunku do zawartości NSP, ligniny Klasona, $\beta$-glukanu i TDF. Usunięcie plewki składającej się głównie z ligniny i nierozpuszczalnych w wodzie hemiceluloz, wpłynęło w sposób znaczący na zawartość składników błonnika pokarmowego $\mathrm{w}$ ziarnie obłuszczonym. Zwiększeniu uległa zawartość $\beta$ glukanu, o $30 \%$, oraz w konsekwencji frakcji rozpuszczalnej NSP, 45\%, a zmniejszyła sie zawartość nierozpuszczalnej frakcji NSP, o 77\%, i ligniny, 58\%. Tym samym zawartość TDF zmniejszyła się o $58 \%$.

\section{Wnioski}

1. Lokalizacja uprawy ma istotny wpływ na zawartość białka, skrobi i SSO w ziarnie oplewionym, natomiast po obłuszczeniu ziarna wykazano jej istotny wpływ również w przypadku zawartości lipidów.

2. W odniesieniu do składników nieodżywczych wykazano istotność wpływu lokalizacji uprawy na zawartość S-NSP i T$\mathrm{NSP}$, ligniny Klasona, $\beta$-glukanu i TDF ziarna oplewionego. Podobne zależności zaobserwowano w przypadku ziarna obłuszczonego.

3. Pod względem zawartości składników odżywczych wyróżniały się odmiany Wendela, Husky i Elegant, zaś pod względem zawartości składników bioaktywnych, Kasztan i Hurdal.

\section{Literatura}

AACC International. Approved Methods of Analysis, 2003.

Englyst, H. N., Cummings, J. H. 1984. Simplified method for the measurement of total non-starch polysaccharides by gas-liquid chromatography of constituent sugars as alditol acetates. Analyst, 109 (7): $937-942$.

Knudsen, K. E. B., Li, B. W. 1991. Determination of oligosaccharides in protein-rich feedstuffs by gas-liquid chromatography and high-performance liquid chromatography. Journal of Agricultural and Food Chemistry, 39 (4): 689 - 694.

Marchello, J. A., Dryden, F. D., Hale, W. H. 1971. Bovine Serum Lipids. I. The Influence of Added Animal Fat to the Ration 1. Journal of Animal Science, 32 (5): 1008 -1015 .

Theander, O., Aman, P., Westerlund, E., Andersson, R., Pettersson, D. 1995. Total dietary fiber determined as neutral sugar residues, uronic acid residues, and Klason lignin (the Uppsala method): collaborative study. Journal of AOAC International, 78 (4): 1030 - 1044.

Tiwari, U., Cummins, E. 2011. Meta-analysis of the effect of $\beta$-glucan intake on blood cholesterol and glucose levels. Nutrition, 27(10): $1008-1016$.

$\underline{\text { Sponsorzy konferencji Dzień Młodego Naukowca } 2018}$

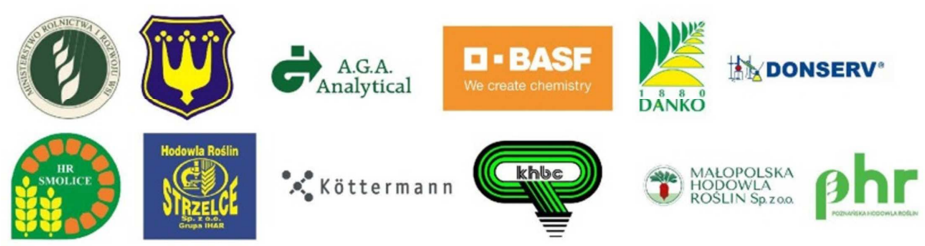

